\title{
MAKNA "MEMANCING" BAHASA BALI DIALEK DESA LEMBONGAN: KAJIAN METABAHASA SEMANTIK ALAMI
}

\author{
I Wayan Ana \\ Universitas Warmadewa \\ ana.wayan@gmail.com
}

\begin{abstract}
ABSTRAK
Kata 'memancing' dapat ditemukan di banyak bahasa di dunia dan kata ini unik di Dialek Bahasa Bali Desa Lembongan karena berbagai hiponim. Penelitian ini dimaksudkan untuk mengetahui dan menjelaskan arti "memancing" pada dialek orang Bali di desa Lembongan dan untuk melestarikan leksikon yang hampir punah karena pesatnya perkembangan pariwisata. Untuk menganalisis permasalahan penelitian ini, teori NSM diterapkan pada konsep semantik primitif, polysemy, allolection, dan sintaks universal. Teori NSM dalam fase menganalisis arti "ikan" di BBDL adalah konfigurasi komponen untuk mengetahui ciri khas, dan penjelasan untuk mempelajari informasi tentang arti "ikan" yang mencakup entitas yang dipaksakan oleh perawatan, penggunaan peralatan, keunikan pergerakan dan hasil yang diharapkan. Dari analisis tersebut, ditemukan bahwa ada tujuh leksikon yang memiliki arti "memancing" dengan ciri khas, yaitu: memelas, ngerumik, ngulur, melok, muduk, maidang dan nyogonang.
\end{abstract}

Kata Kunci: memancing, NSM, dan hiponimy

\begin{abstract}
[Title: Meaning of "Memancing"Balinese Language of Lembongan Village Dialect : The Study of Natural Semantics Metalanguage] The word 'memancing" (fishing) can be found in most languages in the world and this word is unique in the Balinese Language of Lembongan Village Dialect as it various hyponymies. This research is intended to recognize and explain the meaning of "memancing" in Balinese of Lembongan Village Dialect and to preserve the lexicons that are almost extinct due to the rapid development of tourism. To analyze the problems of this research, the NSM theory is applied to the concept of semantic primitive, polysemy, allolection, and universal syntax. The phases of NSM theo$r y$ in analyzing the meaning of "memancing" in BBDL are configurations of components to find out distinctive features, and explication to study the information on the meaning of "memancing" which includes entity imposed by the treatment, the equipment use, the uniqueness of movement and the expected proceeds. From the analysis, it is found that there are seven lexicons having the meaning of "memancing" with distinctive features, namely: memelas, ngerumik, ngulur, melok, muduk, maidang dan nyogonang.
\end{abstract}

Keywords: memancing, NSM, and hiponimy

\section{PENDAHULUAN}

Pada tahun 1970an, mendengar nama Nusa Lembongan saja orang-orang sudah takut, bukan karena pulau ini dihuni oleh hantu ataupun binatang buas atau hal-hal lain yang menyeramkan tetapi karena letak geografisnya yang jauh dari daratan pulau Bali dan keadaan daerahnya yang berbatu dan sangat tandus. Nusa Lembongan adalah sebuah pulau kecil diantara tiga pulau di Kabupaten 


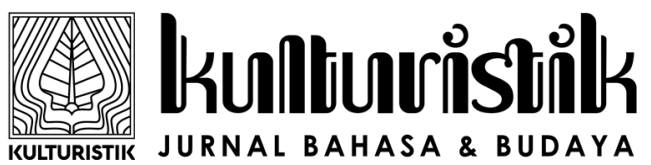

Vol. 1, No. 1, Juli 2017, 13

Available Online at https://ejournal.warmadewa.ac.id/index.php/kulturistik DOI: http://dx.doi.org/10.22225/kulturistik.1.1.213

Klungkung, yaitu: Nusa Penida (sebagai kecamatan dengan ibu kotanya Sampalan), Nusa Lembongan yang terdiri dari dua desa: Desa Jungutbatu dan Desa Lembongan dan Nusa Ceningan sebagai Pulau terkecil diantara ketiga pulau tersebut. Nusa Ceningan sendiri termasuk wilayah Desa Lembongan baik secara adat maupun dinas. Nusa Lembongan dan Nusa Ceningan dipisahkan oleh laut pasang surut. Sehingga penduduk Nusa Ceningan harus naik jukung (transportasi laut tradisional) atau menunggu pasang surut kalau ingin ke Nusa Lembongan. Tetapi untunglah, sekitar tahun 1990an ada jembatan gantung yang menghubungan kedua pulau ini sehingga komunikasi menjadi semakin lancer baik bagi pejalan kaki maupun kendaraan bermotor roda dua. Bahkan jembatan ini sekarang menjadi ikon wisata Desa Lembongan sebagai "Jembatan Kuning (The Yellow Bridge)" dan banyak yang menyebutnya sebagai "Jembatan Cinta" karena sangat romantik untuk swa foto. Jarak tempuh dari Sanur ke Nusa Lembongan pada tahun 1970an adalah sekitar setengah hari dengan perahu layar dan mendayung. Itulah sebabnya kepulauan Nusa Penida, Lembongan dan Ceningan pada tahun tersebut sangat terisolir. Letak geografis inilah yang menyebabkan Desa Lembongan memiliki dialek bahasa Bali yang sangat unik bahkan dengan desa di sebelahnya (Jungutbatu) sangat jauh berbeda. Sebagai contoh misalnya, pengucapan vokal [e] pada posisi akhir "kije" /kijə/ diucapkan /kijas/, "kije ne" / kijo né/ diucapkan /kijas nae/. Keunikan dialek ini sulit dimengerti oleh penutur bahasa Bali dari desa-desa atau daerah lain, apalagi penutur tersebut baru dua-tiga hari berkomunikasi dengan penutur bahasa Bali dialek Desa Lembongan. Keunikan dialek Desa Lembongan ini didukung pula oleh kehidupan mata pencaharian masyarakatnya, yaitu petani-nelayan tradisional. Petani-nelayan tradisional yang dimaksud adalah masyarakat desa yang laki-laki pergi menangkap ikan pagi sampai siang hari, kadang-kadang malam hari, tetapi pada saat tidak melaut mereka bercocok tanam sesuai dengan musim, antara lain, menanam ketela pohon, jagung dan kacang-kacangan serta beternak sapi dan babi. Sedangkan yang perempuan, pada umumnya membantu laki-laki di kebun, atau mencari rumput laut. Dengan kondisi kehidupan seperti ini, secara otomatis mereka hanya berkomunikasi dengan lingkungan terbatas saja. Bahkan kelompok nelayan tradisional di desa ini memiliki sejumlah kata yang hanya dimengerti oleh mereka, dan kurang dipahami oleh masyarakat desa yang bukan bermatapencaharian nelayan, apalagi oleh masyarakat lain di luar desa atau daerah. Salah satunya adalah kata "memancing" yang menurut dialek Desa Lembongan diucapkan "[maciy]" memiliki sejumlah leksikon yang secara umum bermakna "memancing" tetapi dengan ciri yang berbeda. Ciri leksikon dari kata "[macrn]" ini bisa digambarkan melalui telaah mendalam dengan menggunakan pendekatan metabahasa, khususnya Metabahasa Semantik Alami (MSA) (Sudipa, 2012).

Penelitian verba Bahasa Bali sudah banyak dilakukan, di antaranya, Makna "Mengikat" Bahasa Bali: Pendekatan Metabahasa Semantik Alami (Sudipa, 2012b), Frasa Bahasa Bali Kuna dan Perkembangannya ke Bahasa Bali Modern (Beratha, 2012) akan tetapi penelitian tentang verba "mancing dibaca [macin]" dalam Bahasa Bali Dialek Desa Lembongan (BBDL) belum pernah dilakukan oleh ahli atau peneliti lain. Penelitian ini sangat menarik dilakukan karena tindakan "memancing" ini memiliki aktivitas yang kompleks (complex physical activities) yang meliputi motivasi, entitas yang diperlakukan, alat yang digunakan, cara melakukan tindakan, pelaku dan dan hasil yang diperoleh. Verba "memancing" memiliki fitur semantik khusus yang disebut subtle difference 
(Goddard, 1997dalam )Sudipa, 2012:50), yang melekat pada leksikonleksikonnya. Leksikon-leksikon tersebut membentuk konfigurasi makna pembeda antara leksikon yang satu dengan yang lain, khususnya yang berada dalam satu medan makna. Ciri-ciri pembeda ini dapat dieksplikasi dengan menerapkan teori MSA (Wierzbicka, 1996).

Masalah utama yang ingin dipecahkan di dalam penelitian ini adalah realisasi verba "memancing" yang dieksplikasikan berdasarkan teori MSA. Di samping realisasi verbanya, penelitian ini juga ingin mengetahui fitur-fitur pembeda dari verba yang termasuk di bawah hipernim "memancing" dalam BBDL.

Dari pemecahan masalah utama tersebut, penelitian ini dimaksudkan untuk mendapatkan gambaran mengenai realisasi dan fitur verba "memancing" dalam BBDL. Di samping itu, ada keinginan yang kuat untuk melestarikan kasanah bahasa yang pernah ada di masayarakat nelayan tradisional Desa Lembongan yang semakin punah sebagai akibat kemajuan pariwisata yang berkembang pesat dari tahun 2000an.

Untuk membedah permasalahan di dalam penelitian ini diterapkan teori Metabahasa Semantik Alami (MSA) yang berasal dari Anna Wierzbicka pada tahun 1970an dan dikembangkan lebih lanjut terutama oleh Anna Wierzbicka dan Cliff Goddard. MSA didasarkan pada tiga asumsi dasar: 1) metabahasa semantik alami digunakan untuk mendifinisikan semua kata dalam setiap bahasa; 2) metabahasa ini didasarkan atas seperangkat seperti inti kata yang tidak dapat didefinisikan yang disebut sebagai asali, dan tata bahasa yang sederhana. Hasil dari proses analisis MSA ini disebut eksplikasi; 3) makna asali ini dengan tata bahasanya yang sederhana dapat ditemukan dalam setiap bahasa alami.

Pendekatan MSA muncul dari makna leksikon. Ada dua pedoman utama untuk mengenali makna asali. Sebagai makna asli, leksikon harus (a) ditemukan dalam setiap bahasa alami, dan (b) tidak dapat didefinisikan melalui makna asali lainnya. Dengan kata lain, semua leksikon (lebih tepatnya, satuan leksikal) dalam semua bahasa dapat dibagi menjadi dua kelompok: makna asali (64, ditambah beberapa sinonim fungsional, aloleksi) dan kata lain. Kata-kata dalam kelompok yang terakhir pada dasarnya dapat dieksplikasikan melalui makna asali. Karena semua versi MSA yang didasarkan atas bahasa yang berbeda dapat diterjemahkan sepenuhnya, maka MSA dapat digunakan untuk mengeksplikasikan kata apapun dalam bahasa apa pun (universal). Dengan demikian MSA menurut Goddard (2010) bukan sekedar obyek kajian untuk satu bahasa saja tetapi merupakan alat untuk analisis dan penelitian kontrastif fenomena makna dalam semua bahasa: tertium comparationis untuk kajian lintas bahasa dan tipologi bahasa.

Cara formal untuk merepresentasikan makna dalam pendekatan MSA adalah dengan eksplikasi makna dalam bentuk parafrasa secara reduktif, yaitu cara untuk menyampaikan dengan kata lain (dalam metabahasa semantik alami) mengenai apa yang penutur sampaikan ketika si penutur mengujarkan ekspresi yang dieksplikasikan. MSA adalah satu-satunya pendekatan yang menggunakan cara parafrasa secara ketat (Goddard, 2010). Banyak pendekatan berusaha untuk menjelaskan makna dengan cara menguraikan, akan tetapi pendekatan baik yang menguraikan atau tidak ada perbedaan yang jelas antara cara deskripsi dan parafrasa. Parafrasa berusaha untuk menangkap perspektif yang lebih dalam (yang kadang-kadang dengan kwalitas orang pertama yang naif, bukan perspektif luas yang lebih canggih dari ahli bahasa, logika). Di samping itu, parafrasa memerlukan rumusan yang dapat dinilai dan jelas bagi penutur yang bersangkutan. Ke- 
jelasan eksplikasi MSA dan hubungan yang erat antara metabahasa dan bahasa yang dijelaskan memudahkan untuk membuat hipotesis dan mengujinya dengan substitusi langsung atau tidak langsung ke dalam konteks pemakaian secara alami dan penilaian langsung terhadap intuisi penutur asli.

\section{METODE}

Data untuk penelitian ini bersumber dari data lisan yang dikumpulkan melalui wawancara langsung dengan 12 nelayan traditional yang ada di Desa Lembongan. Untuk mendapatkan data yang akurat dan saih dipergunakan metode libat cakap (Sudaryanto, 1993). Dengan metode ini peneliti ikut terlibat dalam percakapan dengan subyek penelitian (responden), yaitu masyarakat yang dulu pernah menjadi nelayan tradisional, tetapi sebagai akibat dari perkembangan pariwisata yang luar biasa pesatnya di Desa Lembongan, mereka tidak lagi berprofesi sebagai nelayan tradisional, tetapi sebagai penyedia jasa transportasi wisata, sedangkan pekerjaan sebagai nelayan traditional dilakukan sebagai pengisi waktu luang. Responden yang dipilih untuk dijadikan subyek penelitian ini semuanya berumur di atas 45 tahun. Hal ini disebabkan karena generasi di bawahnya sudah tidak mengenal lagi aktivitas nelayan tradisional, tetapi cendrung bekerja di bidang pariwisata atau bekerja di luar desa, seperti di Denpasar, Badung, Nusa Dua, Kuta dan lain sebagainya. Penelitian ini tidak menggunakan data pendukung dari sumber tertulis, karena sulitnya memperoleh sumber data tulis mengenai pemakaian kata "mancing dibaca [macın]"

\section{PEMBAHASAN}

Dari data yang diperoleh berupa tuturan lisan, kemudian dianalisis menggunakan teori MSA dengan tahapan: (a) pemetaan komponen dan subkomponen sehingga menghasilkan konfigurasi makna sebagai petunjuk untuk menemukan fitur distingtif (b) eksplikasi makna untuk memperoleh informasi mengenai leksikon "memancing" yang meliputi cara melakukan entitas, perlengkapan yang dipakai, kekhususan kegiatan, perolehan atau hasil yang diinginkan dari kegiatan tersebut. Fitur-fitur semantik masing-masing leksikon akan terurai dengan jelas dari eksplikasinya. Leksikon-leksikon yang merupakan hiponim dari "memancing" ( "mancing dibaca [macıy] dalam dialek Desa Lembongan") yang ditemukan dan n dibahasa di dalam penelitian ini adalah melas atau memelas, ngerumik, ngulur, melok, muduk, maidang dan nyogonang.

Pelaku dari aktivitas melas atau memelas ini adalah manusia dengan fitur harus laki-laki (karena tidak ada perempuan yang melakukan aktivitas melas), dewasa (umur di atas 15 tahun karena harus memiliki tenaga yang cukup kuat untuk mendayung jukung, mengendalikan jukung, menarik ikan besar dan sudah bisa memahami pasang air, arah arus, dan cuaca menurut kalender Bali). Entitas dari aktivitas memelas ini adalah bernyawa berupa ikan yang hidup di laut luas. Lokasi aktivitas memelas bisa di duluan (sebelah timur atau timur laut lokasi desa nelayan tradisional) atau di teben (di sebelah barat laut, barat atau barat daya desa). Untuk bisa melakukan aktivitas melas ini, nelayan tradisional harus menggunakan jukung yang dilengkapi dengan layar dan dayung serta peralatan jukung lainnya. Sedangkan sarana untuk menangkap ikan digunakan kail yang diikatkan pada tali nilon dengan ukuran antara Nomor 200 - 1000 (ukuran nilon tali pancing untuk melas) dan pada mata pancing dihiasi dengan bebulu yang berfungsi sebagai semacam umpan untuk menarik ikan tongkol, tuna atau sejenisnya 
yang terbuat dari bulu kambing atau domba, benang katun dan kadang-kadang dilengkapi dengan benang emas. Karena ketika ditarik bebulu ini akan terlihat mirip seperti cumi-cumi kecil atau udang-udang kecil. Agar jukung bisa bergerak maju untuk menarik tali pancing maka digunakan layar, tetapi apabila tidak ada angin maka nelayan harus mendayung.

Bagaimana cara kerja memelas ini? Nelayan tradisional memang sangat paham dengan system dan arah angin dan mereka sangat paham bahwa malam hari angin berembus dari darat ke laut sedangkan siang hari angin berembus dari laut ke darat. Dengan pengetahuan ini, nelayan berangkat melas pukul 4 pagi, dengan harapan ada angin darat mendorong ke tengan laut ke lokasi memelas (memancing) yang berjarak kurang lebih 3-4 mil dari pinggir pantai. Sampai di lokasi sudah hampir pagi para nelayan menurunkan tali pancing. Dan mereka akan balik ke darat sekitar pukul 8 ke atas dengan harapan ada angin laut yang mendorong mereka ke pesisir, sehingga tenaga untuk mendayung bisa dihemat.

Dari aktivitas memancing ini mereka mendapat hasil yang sangat sepesifik berupa ikan tongkol (be awan istilah Desa Lembongan), cakalan (cekalan), tuna (kunyitan). Pada umumnya nelayan tradisional melakukan aktivitas ini dengan senang hati yang dapat digambarkan dengan pemetaan komponen " $\mathrm{X}$ menginginkan ini", dan nelayan tradisional berharap memperoleh tangkapan yang banyak dari aktivitas ini "banyak Y yang diperoleh", tetapi tidak sedikit yang sedih atau bahkan jengkel karena tidak memperoleh hasil yang diinginkan dan harus mengeluarkan tenaga yang banyak mendayung dari darat ke laut atau sebaliknya karena tidak ada angin. Explikasinya dapat diuraikan sebagai berikut:

Pada saat itu, X melakukan sesuatu terhadap Y

Karena adanya kegiatan $\mathrm{X}$ telah terjadi sesuatu pada $\mathrm{Y}$

$\mathrm{X}$ melakukan ini menggunakan suatu sarana (jukung, bebulu)

Sesuatu terjadi pada Y (tertangkap)

$\mathrm{X}$ mengharapkan hal ini

Hampir sama dengan melas, pelaku dari aktivitas ngulur ini adalah manusia dengan fitur harus laki-laki (karena tidak ada perempuan yang melakukan aktivitas ngulur), dewasa (karena harus memiliki tenaga yang cukup kuat untuk mendayung dan mengendalikan jukung, dan sudah bisa memahami pasang air, arah arus, dan cuaca menurut kalender Bali). Entitas dari aktivitas ngulur ini adalah bernyawa berupa ikan yang hidup di karang-karang dengan kedalam 30 meter atau lebih. Lokasi aktivitas ngulur tidak begitu jauh sekitar 100 meter dari pesisir dan pada umumnya di teben (di sebelah barat laut, barat atau barat daya desa nelayan tradisional). Untuk bisa melakukan aktivitas ngulur ini, nelayan tradisional harus menggunakan jukung kecil tanpa layar dan dayung serta peralatan jukung lainnya. Sedangkan sarana untuk menangkap ikan digunakan kail yang diikatkan pada tali nilon dengan ukuran antara Nomor 100 - 400 (ukuran nilon tali pancing) dan memakai umpan berupa omang-omang (keong), atau ikan tongkol yang diiris -iris kecil, atau lur barak (cacing laut yang berwarna merah).

Aktivitas ngulur ini pada umumnya dilakukan pada pagi sampai siang hari selama kurang lebih dua-tiga jam. Nelayan harus mendayung jukungnya sampai di lokasi. Di lokasi, nelayan tidak mendayung lagi hanya menurunkan tali pancing yang sudah berisi umpan dan menggerakannya naik-turun (ngulur). Dari aktivitas ngulur ini mereka mendapat hasil berupa ikan karang dengan ukuran 
kecil sampai sedang. Pada umumnya nelayan tradisional melakukan aktivitas ini dengan senang hati yang dapat digambarkan dengan pemetaan komponen " $\mathrm{X}$ menginginkan ini", dan nelayan tradisional berharap memperoleh tangkapan yang banyak dari aktivitas ini "banyak Y yang diperoleh". Explikasinya dapat digambarkan sebagai berikut:

Pada saat itu, X melakukan sesuatu terhadap Y

Oleh karena itu terjadi sesuatu pada $\mathrm{Y}$

$\mathrm{X}$ melakukan kegiatan ini dengan menggunakan suatu sarana (jukung, pancing dengan umpan)

Sesuatu terjadi pada Y (tertangkap)

$\mathrm{X}$ menginginkan ini

Berbeda dengan melas dan ngulur, pelaku dari aktivitas ngerumik ini adalah manusia dengan fitur harus laki-laki yang dewasa maupun anak-anak (kalau anakanak pada umumnya mereka melakukannya berdua atau bertiga). Entitas dari aktivitas ngerumik ini adalah bernyawa berupa ikan yang hidup di karang-karang dengan kedalam 10-15 meter. Lokasi aktivitas ngerumik tidak jauh dari pinggir pantai sekitar 50-60 meter dari pesisir dan pada umumnya masih di muara pantai. Untuk bisa melakukan aktivitas ngerumik ini harus menggunakan jukung kecil tanpa layar dan dayung serta peralatan jukung lainnya. Sedangkan sarana untuk menangkap ikan digunakan kail (pancing kecil) yang diikatkan pada tali nilon dengan ukuran paling besar Nomor 100 (ukuran nilon tali pancing) dan memakai umpan berupa omang-omang (keong), atau atau lur barak atau putih (cacing laut yang berwarna merah atau putih).

Aktivitas ngerumik ini pada umumnya dilakukan pada pagi sampai siang hari selama kurang lebih dua-tiga jam. Agar bisa melakukan aktivitas ini harus sedikit mendayung jukung kecil ke tengah (lokasi). Di lokasi, pemancing tidak mendayung lagi hanya menurunkan tali pancing yang sudah berisi umpan. Disebut ngerumik karena aktivitasnya cukup rumit, pancing sering nyangkut di karang dan ikan yang diperoleh juga beraneka ragam dan warna ikan karang. Pada umumnya nelayan tradisional melakukan aktivitas ini dengan senang hati dan cendrung sebagai hiburan serta untuk mendapat ikan yang bisa dikonsumsi sendiri, bukan mata pencaharian. Aktivitas ini dapat digambarkan dengan pemetaan komponen "X menginginkan ini", dan nelayan tradisional berharap memperoleh tangkapan dari aktivitas ini "banyak Y yang diperoleh". Explikasinya dapat diilustraikan sebagai berikut:

Pada saat itu, X melakukan sesuatu terhadap Y

Karena itu terjadi sesuatu pada $Y$

$\mathrm{X}$ melakukan kegiatan ini dengan menggunakan suatu (sarana jukung, pancing dengan umpan)

Terjadi sesuatu pada Y (tertangkap)

$\mathrm{X}$ mengharapkan ini

Hampir sama dengan ngerumik, pelaku dari aktivitas melok ini adalah manusia dengan fitur harus laki-laki anak-anak (jarang sekali orang dewasa melakukan aktivitas melok kecuali untuk melatih anak-anak atau adiknya). Masyarakat nelayan tradisional Desa Lembongan sudah mengenal prinsip 
Vol. 1, No. 1, Juli 2017, 18

Available Online at https://ejournal.warmadewa.ac.id/index.php/kulturistik DOI: http://dx.doi.org/10.22225/kulturistik.1.1.213

ekonomi sejak dulu kala. Aktivitas melok ini tidak memperoleh hasil yang cukup, hanya sebatas kegiatan anak-anak pada hari minggu atau musim liburan. Orang dewasa lebih memilih memelas, atau ngulur atau bercocok tanam. Entitas dari aktivitas melok ini adalah bernyawa berupa ikan yang hidup di area rumput laut atau dasar pantai dengan kedalam 0,5-3 meter. Lokasi aktivitas melok ini hanya di pinggir pantai sekitar 10-25 meter dari pinggir pantai. Untuk bisa melakukan aktivitas melok ini menggunakan jukung kecil tanpa layar dan dayung serta peralatan jukung lainnya. Sedangkan sarana untuk menangkap ikan digunakan kail yang sangat kecil (pancing kecil sekali berwarna hitam) yang diikatkan pada tali nilon dengan ukuran paling besar Nomor 50 (ukuran nilon tali pancing) dan memakai umpan berupa lur putih (cacing laut yang berwarna putih).

Aktivitas melok ini pada umumnya dilakukan pada pagi hari maksimal selama dua-tiga jam. Agar bisa melakukan aktivitas ini harus sedikit mendayung jukung kecil ke tengah (lokasi). Di lokasi, pemancing tidak mendayung lagi hanya melempar tali pancing yang sudah berisi umpan. Disebut melok karena ikan yang diperoleh bernama pelok-pelok dengan beraneka warna. Pada umumnya anak-anak melakukan aktivitas ini dengan senang hati dan sebagai hiburan serta untuk mendapat ikan yang bisa dikonsumsi sendiri, bukan mata pencaharian. Aktivitas ini dapat digambarkan dengan pemetaan komponen " $\mathrm{X}$ menginginkan ini", dan anak-anak berharap memperoleh tangkapan dari aktivitas ini "banyak Y yang diperoleh". Explikasinya dapat digambarkan sebagai berikut:

Pada saat itu, X melakukan sesuatu terhadap Y

Oleh karena itu telah terjadi sesuatu pada $\mathrm{Y}$

$\mathrm{X}$ dalam melakukan kegiatan ini menggunakan suatu sarana (jukung, pancing dengan umpan)

Sesuatu terjadi pada Y (tertangkap)

$\mathrm{X}$ mengharapkan hal ini

Walaupun sama-sama memancing ikan, muduk sangat berbeda. Pelaku dari aktivitas muduk ini adalah manusia dengan fitur harus laki-laki anak-anak. Entitas dari aktivitas muduk ini adalah bernyawa berupa ikan yang hidup di pinggir pantai. Lokasi aktivitas muduk ini dilakukan dari pinggir pantai saja tanpa menggunakan jukung. Sedangkan sarana untuk menangkap ikan digunakan kail sangat kecil (pancing kecil sekali berwarna hitam) yang diikatkan pada tali nilon dengan ukuran paling besar Nomor 50 (ukuran nilon tali pancing) dan memakai umpan berupa lur putih (cacing yang berwarna putih).

Aktivitas muduk ini pada umumnya dilakukan pada sore hari dan sangat singkat maksimal satu jam tergantung pasang surut. Disebut muduk karena ikan yang diperoleh bernama muduk. Pada umumnya anak-anak melakukan aktivitas ini dengan senang hati dan hanya sebagai hiburan saja, bukan mata pencaharian. Aktivitas ini dapat digambarkan dengan pemetaan komponen " $\mathrm{X}$ menginginkan ini", dan anak-anak berharap memperoleh ikan muduk dari aktivitas ini "banyak Y yang diperoleh". Explikasinya dapat digambarkan sebagai berikut:

Pada saat itu, X melakukan sesuatu terhadap Y

Karena itu pada waktu bersamaan sesuatu terjadi pada $Y$

$\mathrm{X}$ dalam melakukan kegiatan ini menggunakan sarana (pancing dengan umpan)

Sesuatu terjadi pada Y (tertangkap) 


\section{$\mathrm{X}$ menginginkannya}

Pelaku dari aktivitas maidang ini adalah manusia dengan fitur harus lakilaki dewasa atau anak-anak. Aktivitas maidang ini sebagai pengisi waktu kosong saat tidak memelas untuk mencari ikan untuk konsumsi sendiri. Ikan yang diperoleh pada umumnya ikan yang bagus, yaitu ikan cucut (pasuh istilah Desa Lembongan). Entitas dari aktivitas maidang ini adalah bernyawa berupa ikan yang hidup di permukaan laut. Lokasi aktivitas maidang ini di pinggir pantai sekitar 10-25 meter dari pinggir pantai. Untuk bisa melakukan aktivitas maidang ini harus menggunakan jukung kecil tanpa layar dan dayung serta peralatan jukung lainnya. Sedangkan sarana untuk menangkap ikan digunakan kail yang diikatkan pada tali nilon dengan ukuran paling besar Nomor 100 (ukuran nilon tali pancing) dan memakai umpan berupa udang atau ikan teri.

Aktivitas maidang ini pada umumnya dilakukan pada musim-musim tertentu dimana ikan permukaan berupa cucut banyak yang datang ke pinggir pantai. Agar bisa melakukan aktivitas ini harus mendayung jukung kecil secara terusmenerus untuk menarik tali pancing. Disebut maidang karena tali pancing dan umpan ditarik (paid dalam bahasa Bali). Pada umumnya aktivitas ini dilakukan dengan senang hati dan sebagai hiburan serta untuk mendapat ikan yang bisa dikonsumsi sendiri, bukan mata pencaharian. Aktivitas ini dapat digambarkan dengan pemetaan komponen "X menginginkan ini", dan berharap memperoleh tangkapan dari aktivitas ini "banyak Y yang diperoleh". Explikasinya dapat digambarkan sebagai berikut:

Pada saat itu, X melakukan sesuatu terhadap Y

Karena itu telah terjadi sesuatu pada Y

$\mathrm{X}$ melakukan ini dengan menggunakan suatu sarana (jukung, pancing dengan umpan)

Terjadi sesuatu pada Y (tertangkap)

$\mathrm{X}$ mengharapkan ini

Nyogonang sebenarnya sama dengan maidang. Yang membedakan kedua aktivitas ini adalah umpan yang digunakan dan waktu untuk melakukan kegiatan ini. Umpan yang digunakan adalah bebulu sama seperti memelas, tetapi aktvitas ini dilakukan pada malam hari, kadang-kadang dari jam 7 malam sampai jam 9 malam menjelang bulan mau terbenam, atau pada saat menjelang pagi, menjelang bulan hampir terbenam. Pada umumnya nyogonang ini dilakukan mulai dari lima hari setelah bulan mati (penanggal 5 ke atas), tetapi juga ditentukan oleh sasih (Kalender Bali). Disebut nyogonang karena ikan yang ditangkap tersebut bernama ikan sogo. Pada umumnya aktivitas ini dilakukan dengan senang hati dan merupakan mata pencaharian. Aktivitas ini dapat digambarkan dengan pemetaan komponen "X menginginkan ini", dan berharap memperoleh tangkapan dari aktivitas ini "banyak Y yang diperoleh". Explikasinya dapat digambarkan sebagai berikut:

Pada saat itu, X melakukan sesuatu terhadap Y

Karena itu pada waktu bersamaan terjadi sesuatu pada $Y$

$\mathrm{X}$ dalam melakukan kegiatan ini menggunakan suatu sarana (jukung, pancing dengan bebulu sebagai umpan)

Sesuatu terjadi pada Y (tertangkap) 
$\mathrm{X}$ menginginkan hal ini

\section{SIMPULAN}

Teori MSA menggunakan konsep makna asali, polisemi, aloleksi dan sintaksis universal dalam menganalisis makna. Cara kerjanya adalah membatasi makna kata dengan menggunakan teknik parafrase. Deskripsi maknanya bersifat tuntas dan tidak berputar-putar. Tahapan kerja teori MSA dalam menganalisis makna "memancing" BBDL adalah pemetaan komponen untuk menemukan fitur distingtif, dan dilanjutkan dengan eksplikasi makna untuk memperoleh informasi mengenai leksikon "memancing" yang meliputi entitas yang dikenai perlakuan, alat yang digunakan, kekhasan gerakan, dan hasil yang diharapkan. Dari analisis di dalam pembahasan ditemukan bahwa verba "memancing" sebagai hipernim dapat direalisasikan ke dalam tujuh leksikon yang memiliki makna tetapi dengan fitur yang yang berbeda, yaitu: memelas, ngerumik, ngulur, melok, muduk, maidang dan nyogonang.

Leksikon memelas memiliki fitur distingtif dengan 6 leksikon memancing lainnya. Leksikon ini memiliki fitur lokasi yang jauh dari pantai nelayan tradisional, lepas (palas atau melas). Ngerumik memiliki fitur distingtif lokasi tetapi bukan karena jauhnya tetapi kerumitan (rumik) aktivitas memancing itu sendiri. Ngulur dan maidang memiliki fitur distingtif dilihat dari cara melakukan aktivitas memancing tersebut. Melok, muduk dan nyogonong dibedakan dari aktivitas memancing lainnya dari sudur hasil tangkapannya. Melok pada umumnya menangkap ikan pelok-pelok (nama ikan), muduk memperoleh ikan muduk dan nyogonang memperoleh ikan sogo.

\section{DAFTAR PUSTAKA}

Beratha, N. L. S. (2012). Frasa Bahasa Bali Kuna dan Perkembangannya ke Bahasa Bali Modern. Jurnal Kajian Bali, 2(2), 69-86.

Goddard, C. C. (1997). Semantic analysis: a practical introduction. Australia: The University of New England Armidale.

Goddard, C. C. (2010). Natural semantics metalanguage approach. Oxford: Oxford University Press.

Sudaryanto. (1993). Metode dan aneka teknik analisis bahasa. Jakarta: Duta Wacana University Press.

Sudipa, I. N. (2012a). Makna "mengikat" bahasa bali: pendekatan metabahasa semantik alami.

Sudipa, I. N. (2012b). Makna "Mengikat" Bahasa Bali: Pendekatan Metabahasa Semantik Alami. Jurnal Kajian Bali, 2(2), 49-68.

Wierzbicka, A. (1996). Semantics: primes and universals. New York: Oxford University Press. 